\title{
Job Satisfaction and Work Motivation in Enhancing Generation Z's Organizational Commitment
}

\author{
Putri Rakhmatia Nabahani, Setyo Riyanto \\ Mercu Buana University, Jakarta Indonesia and \\ Mercu Buana University, Jakarta Indonesia \\ Email:putrirakhmatia@gmail.com and setyo.riyanto@mercubuana.ac.id
}

\section{ARTICLE INFO}

Date received : 01 August 2020

Revision date : 07 September 2020

Date received : 20 October 2020

\section{Keywords:}

Generation Z,

Human Resource,

Employee Management,

Organizational Commitment

\begin{abstract}
Generation $\mathrm{Z}$ is a generation with unique characteristics that makes them differ from their predecessor. With Generation Z entering the workplace, there are currently three generations (Gen X, Gen Y, and Gen Z) that must work together and coordinate within the company. However, Generation $Z$ is known to be a "job hopper" generation. They like to switch between jobs for a certain reason. This behavior is surely associated with the concept of organizational commitment. Furthermore, both variables (motivation and satisfaction in work) presumed to have a great impact on organizational commitment. Therefore, the aim of this study is to observe on how to enhance Generation Z's organizational commitment through job satisfaction and work motivation. This observation is to explain on what Generation Z expects and values the most in the workplace and how employers can meet those expectations. Research method used is desktopbased research which consists of secondary data collected from different research papers, journals, articles, and books.
\end{abstract}

\section{INTRODUCTION}

As time goes by, the population of humans is getting bigger. This massive population was later classified into the term of Generations. A Generation is described as a group of people that have similar birth years and comparable life stages in a particular period of time and are influenced by the same social circumstances (Kirchmayer \& Fratricová, 2020). Several studies state that every member that comes from the same generation is presumed to have a similar way of thinking as a consequence of sharing the same economic experiences, unique cultural, and political life (Mccrindle, 2011). The similarity in a way of thinking may lead to different attitudes and behaviors of each generation.

Meanwhile, in the working world, there are currently three generations who must work together and coordinate within the workplace (Meret, Fioravanti, lannotta, \& Gatti, 2018). The three generations are the boomers, born post World War 2; generation $X$, which was born between 1965 to 1976; generation Y, which was born between 1977 to 2000. Moreover, Generation Z, which was born in the early 2000s or in another study includes people born after 1995 has just partially joined the workforce (Mccrindle, 2011).

On the other hand, the main indicator of having a successful business is determined by its human resource. Employees have a direct impact on the overall performance of the company. To accomplish a great performance, employees also need a great leader as their exemplar. The main key to be a good leader is to understand its employee human traits, attitude shifts, social trends, and thinking behavior (Mccrindle, 2011). In the workforce, the main factor that affects employees' behavior is due to the diversity in generations. Consequently, the difference in generations would form various expectations of work characteristics and work preferences. 
An understanding of every generation plays a crucial part to engage and maintain the potential workforce (Kirchmayer \& Fratricová, 2020) especially in the generation that has just entered the workforce, Generation Z. Therefore, every manager should have an insightful understanding of its employees (Meret et al., 2018).

Generation $\mathrm{Z}$ is known as a group of people that were born in a digital technology world (Meret et al., 2018). The technologies have a big impact on human activities and the fact that Generation $Z$ is matured alongside technology leads to an assumption that Generation $Z$ has made the technology as their personalities. They could be as creative and innovative as they wanted to be with all the accessibility and limitless information. If they do not like something, they can easily change it with their capabilities (Csiszárik-Kocsír \& Garia-Fodor, 2018). This behavior is surely associated with the concept of organizational commitment. For that reason, it can be presumed that organizational commitment could be a problem for Generation Z. Additionally, several studies on Generation Z's level of commitment shows that unlike earlier generations whom willingly to stay loyal to one company for a long span of time, Generation $\mathrm{Z}$ is most likely to be a "job-hopping" generation, meaning that they do not stay on one company (Beckman, 2018) (Limón, 2019). For particular reasons, they tend to always seek for another job every time they have the opportunity to.

Organizational commitment is a concept that have a close relationship to job satisfaction and work motivation. The more employees get satisfied with their job, the more motivated they are to keep on working their best, vice versa, achievement could be made. With great reward and acknowledgment given by the organization, the more they are satisfied and emerge a sense of belonging, which also nurture sense of loyalty and commitment. Hence, satisfaction, motivation and commitment are unmeasurable aspects. To maintain employees to stay committed, managers should have an understanding about what employees values the most in order to make them satisfied and motivated. Therefore, the aim of this study is to observe how to enhance Generation Z's organizational commitment through job satisfaction and work motivation.

\section{LITERATURE REVIEW Job Satisfaction}

Job satisfaction refers to employees' feelings and emotions towards their effort of work. These feelings could be both positive (satisfaction) and negative (disappointment) (Pawoko, 2019). Various factors that could affect job satisfaction requires every manager to be more aware of its employees' level of satisfaction and dissatisfaction (Manalo, de Castro, \& Uy, 2020). It is a basic principle for an organization in accomplishing the goals and objectives (Masydzulhak \& Anggraeni, 2016). Job satisfaction represents how employees actually feel and think about the task and responsibility that have been given by the company, including whether the tasks fit in their job preferences and expectations or not. Levels of satisfaction will influence how employees think and see the organization. The satisfaction of work could be a motivation for employees to work harder while dissatisfaction of work could be a reason for employees to quit the job.

According to (Colquitt, Lepine, Wesson, \& Gellatly, 2011) employees prefer a job that is interesting and challenging their skills and abilities rather than jobs that are repetitive and do not need any specialties on particular skills. However, the level of satisfaction is an intangible factor that makes it rigorous to be determined and generalized to every employee. In contrast, some employee might prefer a job that does not require a significant responsibility and do not need much efforts. It depends on employees' characteristics, needs, and ways of thinking.

Job satisfaction is associated with employees' attitudes in the workplace (Sihombing, 2019). In addition, there are three components of attitudes: cognitive, affective, and behavioral. The behavioral component of an attitude refers to an intention in behaving in a certain way toward a situation or someone else (Colquitt et al., 2011). This behavioral situation is also associated with working motivation. Hence, the satisfaction of work could influence employees' motivation to stay and come to work which leads to high commitment in the organization (Lawler, 2006).

\section{Work Motivation}

Work Motivation is one key that drives to job commitment. It is defined as a set of impulses to move (or to do something), emerges from both internal and external factors that influence employees (Colquitt et al., 2011). Motivation comes from a Latin word which means move or push which represents a circumstance where an individual feels the urge to move forward (internal motivation) or the feeling of being pushed by the environment (external motivation). It determined the potential of an individual to cooperate productively and successfully in obtaining the intended purpose (Riyanto, Sutrisno, \& Ali, 2017).

Additionally, motivation also determines an employee's work effort (Colquitt et al., 2011). According to Veithzal and Rivai which was cited by Riyanto (2017), motivation can be described as a condition in which employees were encouraged to move forward and work at their best to achieve the company's goal and as an instrument to influence and maintain the employees' behavior in the work environment.

Motivation at work could be formed by interests. The more he/she get interested in their 
work, the more they are motivated. Subsequently, interests are influenced by the characteristic of employees themselves. Other factors that could influence employees' motivation at work besides the work itself are work environment, compensation, work features, and organizational cultures. Hence, motivation is a very relative subject to determined. What motivates an individual does not always work on other employees. Hence, managers are required to do continuity research on motivation to get a better understanding of what motivates employees.

Job satisfaction and work motivation are presumed to have a great impact on organizational commitment. Job satisfaction plays a role as an indicator that elaborates on how employees feel about their work, whether the job or the output is fulfilling their expectations or not. It is not only about accomplishing the company goals, but it is also a matter of what employee desires to have achieved for their benefits. The more employee gets satisfied with their job, the more they are motivated to stay in the company.

\section{Organizational Commitment}

Organizational commitment is defined as the desire of an employee to stay as a member of an organization. It is an act that represents an employee's level of involvement in the organization (Amah \& Oyetunde, 2019). Organizational commitment indicates whether an individual remains an employee of the organization or not (Colquitt et al., 2011). It is a condition in which employees not only care for the organization but also feel the need to maintain their membership to the organization. Moreover, Efendi \& Sutanto describe organizational commitment as an emotional bonding between the employees and the company which leads to the employees feeling like they ought to be responsible for achieving the company's goal (Santoso \& Riyanto, 2020).

The concept of organizational commitment has become a crucial part in assessing employees' loyalty to the company (Suryani, 2018). Commitment acts as an instrument to foresee retention rate and employee's propensity to leave (Balanescu, 2017). According to Loi, et al in (Suryani, 2018), poor level of commitment in the organization will affect a high level of turnover which also impacts high expenses on recruiting and training new employees. However, having talented employees who perform well in work is also not enough, managers need to be able to engage them for a long span of time in order to attain benefit from their efforts.

According to Becker in (Balanescu, 2017) the link amid the organization and its employees is based on the economic exchange "contract", in which the dedicated employees promise loyalty because they hold a total or perhaps partially hidden investments which they attain by staying in the organization. Another study of organizational commitment was later conducted by Meyer and Allen in (Balanescu, 2017). According to them, organizational commitment is a psychological state, which consists of three distinguished elements of the three-dimensional model which cited by (Masydzulhak \& Anggraeni, 2016).

1) Affective commitment, feeling the need to remain due to emotional intervening in the organization.

2) Continuity commitment, the need to remain as an employee due to the thought of risk and cost if they quit the organization

3) Normative commitment, the need to remain as an employee due to the feeling of responsibility of the obligation to ought to stay.

Companies might use this model to attain Generation Z's commitment within the organization. Further research on Gen Z shows that psychological capital (which consists of Hope, Self-efficacy, Optimism, and Resilience) has a positive influence on Gen Z's continuity commitment (Wardhani, Qurniawati, \& Putra, 2020). This shows that understanding the differences in expectations, levels of optimism, efficacy, and resilience of each member of Gen Z matters in order to motivate and maintain employees' satisfaction in working in the organization.

\section{Generation Z}

Characteristics of Gen Z - Generation Z began in the year of 2000 or 1995 until 2009 (Mccrindle, 2011). It is the first generation that matured alongside advanced technologies (Meret et al., 2018), in particular the rapid evolution of how people communicate and interact (Singh \& Dangmei, 2016). According to (Dolot, 2018), many studies describe Generation Z as a connected, communicating, content-centric, computerized, community-oriented, and changing generation. For that reason, they are known as Generation C.

According to (Mccrindle, 2011), during their adolescence or early adulthood, Generation Z has encountered a unique and variety of stimuli, for example, uncertain economic and social circumstances followed by climate change, globalization, growing diversity, and continuous change in digitalization. Those stimuli sure affect how the members of the generation react and respond to certain circumstances. They grew up adapting to changes that occurred in the environment. They are brave, creative, and never lack initiative (Csiszárik-Kocsír \& Garia-Fodor, 2018).

Further insight of Gen Z and its digitalization, the most important thing to consider is that they were raised in an era with the most profound changes, particularly in technologies. internet with limitless accessible information was matured with them. They are familiar with smartphones and digital 
media more than anyone (Singh \& Dangmei, 2016). They also claim themselves as a "digital native", since technologies are natural for them (Williams, 2015). The ability to function in both real and virtual worlds as complementary to one another leads to a limitless amount of information that they could get (Dolot, 2018).

With the uniqueness of stimuli and access to limitless information, generation $Z$ tends to have several values that are different from previous generations. They are task-focused, have more options than ever, more educated, and sophisticated (Mccrindle, 2011). Having an excellent ability and intelligence in absorbing and processing limitless information indicates an even greater ability to multitask and being productive rather than their predecessors (lorgulescu, 2016).

Nevertheless, it is also a matter of fact that "jobhopping" is quite common and normal for them (Beckman, 2018) (Limón, 2019). The term "jobhopping" refers to certain circumstances in which an individual keeps switching between jobs. This behavior is surely associated with the concept of organizational commitment. Furthermore, both satisfaction and motivation of work have a great influence on employees' commitment to the company (Manalo et al., 2020). Therefore, to maintain Gen Z's motivation to work and to fulfill its feeling of satisfaction in the organization, it is very crucial to identify their work preferences and get an insight into their expectation of job (Agarwal \& Vaghela, 2018).

\section{METODE}

The aim of this study is to observe how to enhance Generation Z's organizational commitment through job satisfaction and work motivation. This observation is to explain on what Generation Z values the most in the workplace and how employers can meet those expectations. The method used is desktop-based research. Desktopbased research is one of the data collection methods that rely on secondary data collected from different articles, journals, and other research papers (Johnston, 2017). The data collected is related to characteristics of Generation Z, job satisfaction, work motivation, and their impact on Generation Z's organizational commitment.

According to American scientists, William Strauss and Neil Howe which cited by (Holopainen \& Suslova, 2019), stated that a generational theory is described as a group of people that have the same values, attitudes, and ways of thinking in general. Based on that theory, it can be presumed that the number of respondents studied in earlier researches could be a representative of Generation $Z$ generally.

\section{RESULTS AND DISCUSSION}

According to an empirical study conducted by (ArunKumar, 2014) about the Relationship between Employee Motivation, Satisfaction, and Organizational Commitment on 118 respondents which conclude that motivation and job satisfaction does have a significant impact on organizational commitment. In the research paper, motivation is interpreted as a psychological trait leading to employees' commitment to the organization. Therefore, the organization needs to capture a strategic plan to meet the expectations and motivational factors to keep the employee motivated. Subsequently, through motivated employees, the organization could expect to enhance the job satisfaction level and to build employees' sense of commitment to the organization.

Moving on to the topic of Generation Z, it has been stated that the differences in the characteristics of each generation lead to differentiation in work preferences and expectations. Meeting expectations are crucial as Generation Z tends to have idealistic ideas that the work will be entertaining, meaningful, developing, that every colleague at work will respect and consider their thoughts and ideas, not having to deal with forced working because they expect to have flexibility in schedule, and having an understanding partner (Schroth, 2019).

The fact that Generation $Z$ is a new generation entering the workforce makes it important for managers to get an insight and understand them in order to design a proper generation mix to establish proper communication and a great working environment (Gaidhani, Arora, \& Sharma, 2019). In previous research conducted by Schwabel (Kirchmayer \& Fratricová, 2020), the three most important values that Generation $Z$ is seeking from work are opportunities to grow, making much money, and getting a meaningful and great job. Schwabel's research is in line with Bridges' research cited by Ghaidhani et al (2019). They believe that their education skills and ability are not enough to face real-life problems. Therefore, they expect to have a chance to get an advancement. Sociable and flexible schedules are a motivation for them. They also prefer companies that provide the best technology, since technology is their best advantage.

Meanwhile, another research was conducted by (Meret et al., 2018), which confirms Gen Z's plan in building their future is by getting a higher level of education. Education is a crucial indicator for Gen Z. Getting a higher level of education means having a great opportunity to develop their skills, both soft skills and hard skills. Regarding their strategy to build a bright future, Gen $Z$ desires to work at a multi-national company rather than being an entrepreneur.

The data shown in Figure 1 is a result of research by (Meret et al., 2018) on a total of 298 respondents with an average age of 22,2 years old which categorized as members of Gen Z. From that 
data, we can conclude that there are several aspects that are crucial for Gen Z. The highest answer frequency which could also be interpreted as the most important aspect is the opportunity to learn and develop themselves. This matches up with the fact that Gen $Z$ values knowledge more than anything. The second and third most important aspects for Gen Z are trust and job security.

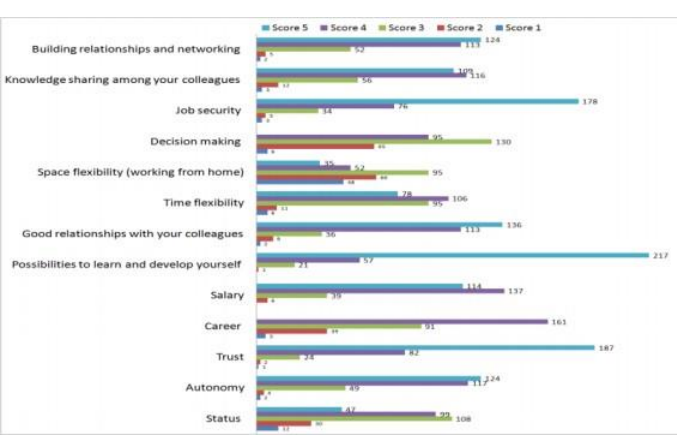

Figure 1. Most important aspects of jobs among Zers. (Source: (Meret et al., 2018) The Digital Employee Experience: Discovering Generation Z.)

Speaking of trust, another research done by (Young, 2020) with a total of over 2000 Zers in the US has made to a conclusion that $67 \%$ of respondents claimed that other people, both in social life and workplace, could not be trusted. Meaning they have a trust issue over other people. They have a strong value which makes it difficult to gain their trust. Transparency and open communication play a crucial thing in establishing deep bonds with Gen Z. Additionally, as trust within the workforce is concerned, Gen $Z$ values toward trust appear to differ from older generations. As mentioned before, Gen $Z$ values knowledge the most, along with experiences, and expertise. Therefore, to gain their respect and trust in work is to have those variables (Lazányi \& Bilan, 2017).

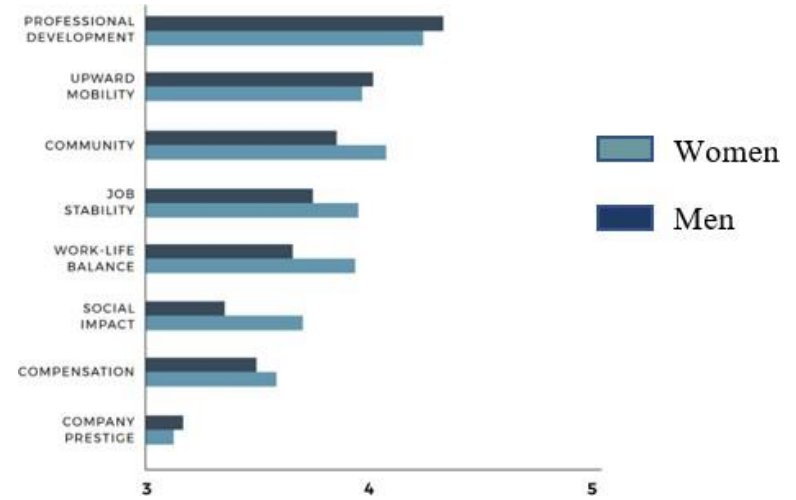

Figure 2. Indicators that Gen Z Values in the Workplace. (Source: (RippleMatch, 2018))

Similar research also conducted by (RippleMatch, 2018), differentiating respondents between gender to visualize the difference. Figure 2 shows that the top three indicators that Gen Z values are professional development, upward mobility, and community. Professional development is important due to their issues of fear of not being good enough. Subsequently, upward mobility comes to number two for men. Meanwhile, women think that community comes first before upward mobility. In general, the two of them are still concerned about upward mobility and community. It is just a matter of ranks. Having a good plan on a career path and having a supportive and communal workplace is both important for them.

As they are expecting to always have an opportunity to learn and develop themselves as much as the desire to have an opportunity to have different job roles and flexibility (Dwidienawati \& Gandasari, 2018), it could be interpreted that Generation Z has an internal issue of fear of not being good enough. This goes to the result of research that conducted by (Dwidienawati \& Gandasari, 2018) on Generation Z in Indonesia, which conclude that Gen $Z$ is not as confident as people thought they'd be. Therefore, it would be much more appreciated if the company offers a personal development program.

Company prestige that comes as the latest indicator that Gen Z values also shows that Gen Z's trust within the company is not always influenced by the big brand name of the company, they prefer to do research on the brand and make their own conclusion about the company and decide whether they want to work there or not. Compensation that comes the second from the last indicators that Generation $Z$ values shows that it is not really matter for them. They prefer to get a meaningful, interesting and great job rather good compensation.

\section{CONCLUSION}

According to research on Gen Z's organizational commitment, it shows that they appear to be more into switching between jobs instead of staying in one for a long time. This circumstance concerns managers particularly in maintaining the company rate of retention and turnover. Nevertheless, many companies nowadays still have the old-fashioned strategy in maintaining its employees. They rely on giving high compensation and their big names to attract employees. For older generations, it may work just fine. But it is different with Generation Z. Generation $Z$ has its own expectations and preferences for a job. Money is surely on their priority list but it is not on their top ranks when considering a job. There are many variables that Generation $Z$ expects and it is more than high compensation. For that reason, companies should have an insight into the new generation in order to understand them.

The most mentioned indicator when considering for $a$ job is whether the company provides development programs. They admire expertise and knowledge which leads to the 
expectation of being able to grow within the company by developing themselves to have better skills and competencies. They prefer jobs that require certain skills and abilities. They enjoy being able to work by implementing their competencies. They also value upward mobility and development programs will give them the opportunity to enhance their ability in attaining the desired career path.

Gen $Z$ values freedom in work, not only in terms of time but also in the type of work itself. As mentioned before, they enjoy being able to work optimizing their skills and abilities shows that having a meaningful job is important for them. They do what they love to do. Identifying what exactly makes it a great and meaningful job for Gen $Z$ is important to motivate and enhance their job satisfaction. On the other hand, open communication with transparency will help in gaining Gen Z's trust within the company. Gen $Z$ values relations and networking with trust. Having a supportive workplace with good relationships between other employees will immensely motivate them.

\section{REFERENCES}

Agarwal, Hemlata, \& Vaghela, Pratiksinh. (2018). Work Values Of Gen Z:Bridging the Gap to the Next Generation. India: Parul University.

Amah, Okechukwu E., \& Oyetunde, Kabiru. (2019). Human resources management practice, job satisfaction and affective organisational commitment relationships: The effects of ethnic similarity and difference. SA Journal of Industrial Psychology, 45(1), 1-11.

ArunKumar, S. (2014). An empirical study: relationship between employee motivation, satisfaction and organizational commitment. International Journal of Management and Business Research, 4(2), 81-93.

Balanescu, Ramona Cristina. (2017). Commitment At The Workplace-Implications At Personal And Organisational Level. Conference Proceedings Of» ELearning and Software for Education "(ELSE), 2(01), 324-330. " Carol I" National Defence University Publishing House.

Beckman, Kate. (2018). Will Gen Z be the Next Generation of Job Hoppers? Retrieved from RippleMatch website: https://ripplematch.com/journal/article/will-genz-be-the-next-generation-of-job-hoppersb04feb4e/

Colquitt, Jason, Lepine, Jeffery A., Wesson, Michael J., \& Gellatly, lan Robert. (2011). Organizational behavior: Improving performance and commitment in the workplace. Amerika: McGraw-Hill Irwin New
York, NY.

Csiszárik-Kocsír, Ágnes, \& Garia-Fodor, Mónika. (2018). Motivation Analysing And Preference System Of Choosing A Workplace As Segmentation Criteria Based On A Country Wide Research Result Focus On Generation Of Z. On-Line Journal Modelling the New Europe, (27), 67-85.

Dolot, Anna. (2018). The characteristics of Generation Z. E-Mentor, 74(2), 44-50.

Dwidienawati, Diena, \& Gandasari, Dyah. (2018). Understanding Indonesia's generation $Z$. International Journal of Engineering \& Technology, 7(3), 245-253.

Gaidhani, Shilpa, Arora, Lokesh, \& Sharma, Bhuvanesh Kumar. (2019). Understanding the attitude of generation $\mathrm{Z}$ towards workplace. International Journal of Management, Technology And Engineering, 9, 2804-2812.

Holopainen, Lera, \& Suslova, Aleksandra. (2019). Job Satisfaction and Employee Motivation: Case Generation Z. In The Seus. Finlandia.

Iorgulescu, Maria Cristina. (2016). Generation Z and its perception of work. Cross-Cultural Management Journal, 18(01), 47-54.

Johnston, Melissa P. (2017). Secondary data analysis: A method of which the time has come. Qualitative and Quantitative Methods in Libraries, 3(3), 619-626.

Kirchmayer, Zuzana, \& Fratricová, J. (2020). What motivates generation $Z$ at work? Insights into motivation drivers of business students in Slovakia. Proceedings of the Innovation Management and Education Excellence through Vision, 6019-6030.

Lawler, Edward E. (2006). Job Attitudes and Employee Motivation: Theory, Research and Practice. Psychology and Industrial Productivity, 23(2), 5-22.

Lazányi, Kornélia, \& Bilan, Yuriy. (2017). Generetion $Z$ on the labour market: do they trust others within their workplace? Polish Journal of Management Studies, 16(1), 78--93.

Limón, Mariana. (2019). Why are so many Millennials and Gen Z job-hopping? Retrieved from Tecnológico de Monterrey website: https://observatory.tec.mx/edu-news/why-areso-many-millennials-and-gen-z-job-hopping

Manalo, Ronaldo A., de Castro, Belinda, \& Uy, Chin. 
(2020). The Mediating Role of Job Satisfaction on the Effect of Motivation to Organizational Commitment and Work Engagement of Private Secondary High School Teachers in MetroManila. Review of Integrative Business and Economics Research, 9(1), 133-159.

Masydzulhak, Hapzi Ali, \& Anggraeni, dan Leni Dewi. (2016). The Influence of Work Motivation and Job Satisfaction on Employee Performance and Organizational Commitment Satisfaction as an Intervening Variable in PT. Asian Isuzu Casting Center. Journal of Research in Business and Management, 4(10), 1-10.

Mccrindle, M. (2011). An Excerpt FromThe ABC of $X Y Z$ : Understanding the global generations beyond $z$ : meet generation alpha. Amerika: UNSW Press.

Meret, Chiara, Fioravanti, Silvia, Iannotta, Michela, \& Gatti, Mauro. (2018). The digital employee experience: Discovering generation $Z$. In Digital Technology and Organizational Change (pp. 241-256). Amerika: Springer.

Pawoko, Guntur. (2019). The Role of Work-Life Balance, Achievement Motivation on Organizational Commitment through Satisfaction Athlete's in Indonesia. Academy of Strategic Management Journal, 18(5), 1-11.

RippleMatch. (2018). Gen Z In The Workplace. Retrieved from RippleMatch website: https://ripplematch.com/generation-zworkplace-report.pdf

Riyanto, Setyo, Sutrisno, Ady, \& Ali, Hapzi. (2017). The Impact of Working Motivation and Working Environment on Employees Performance in Indonesia Stock Exchange. International Review of Management and Marketing, 7(3), 342-348.
Santoso, Nicolas Bragas Agung, \& Riyanto, Setyo. (2020). The Effect of Work Motivation, Organizational Commitment, and Job Satisfaction on the Contract Employees Performance of $\mathrm{Pt}$ Bank Rakyat Indonesia Branch Office of Jakarta Daan Mogot. International Journal of Innovative Science and Research Technology, 5(1), 561-568.

Schroth, Holly. (2019). Are you ready for Gen Z in the workplace? California Management Review, 61(3), 5-18.

Sihombing, Setyo Riyanto dan Lukertina. (2019). Does the Good Corporate Governance Culture Good for Workers? Journal of Business and Management (IOSR-JBM), 21(8), 15-20.

Singh, A. P., \& Dangmei, Jianguanglung. (2016). Understanding the generation $\mathrm{Z}$ : the future workforce. South-Asian Journal of Multidisciplinary Studies, 3(3), 1-5.

Suryani, Irma. (2018). Factors Affecting Organizational Commitment. Jurnal Manajemen Inovasi, 9(1), 26-34.

Wardhani, Bertha Kusuma, Qurniawati, Rina Sari, \& Putra, Yanuar Surya. (2020). Upaya Peningkatan Komitmen Organisasi Generazi Z Melalui Psychological Capital Dan Organizational Citizenship Behaviour (Studi Kasus Pada Karyawan Generasi Z Di Kota Salatiga). Magisma: Jurnal IImiah Ekonomi Dan Bisnis, 8(1), 9-18.

Williams, Alex. (2015). Move over, millennials, here comes Generation Z. The New York Times, 18, 1-7.

Young, Ernst \&. (2020). Gen Z a generation of contradiction: Generation $Z$ Segmentation Study Top-line findings and the power of five. Retrieved from assets.ey.com website: https://assets.ey.com/content/dam/ey-sites/eycom/en_us/topics/advisory/ey-gen-zcontradictions.pdf

\section{Copyright holder:}

Putri Rakhmatia Nabahani, Setyo Riyanto (2020)

First publication right:

Journal of Social Science

This article is licensed under:

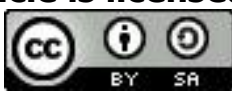

